\title{
THE RELATIONSHIP BETWEEN ATTITUDE TOWARD PROFESSION OF TEACHER AND LIBRARY SERVICE WITH LEARNING MOTIVATION AND ACHIEVEMENT OF STUDENTS
}

\author{
Agus Sugianto \\ STKIP Bina Insan Mandiri Surabaya, Indonesia \\ agoessg@gmail.com \\ Bambang Budi Wiyono \\ Department of Education Management, State \\ University of Malang, Indonesia \\ bambang.budi.fip@um.ac.id
}

\author{
Ali Imron \\ Department of Education Management, State \\ University of Malang, Indonesia \\ ali.imron.fip@um.ac.id \\ Imron Arifin \\ Department of Education Management, State \\ University of Malang, Indonesia \\ imron.arifin.fip@um.ac.id
}

\begin{abstract}
Research aims to describe and explain directly and indirectly the relationship of the attitude to profession of teacher, quality of lecturer's skill in teaching, library service with learning motivation and learning achievement of Sekolah Tinggi Keguruan dan Ilmu Pendidikan (STKIP) students in East Java. Research design uses survey research with descriptivecorrelation approach. Research population is 2169 STKIP students in East Java which are taken by 200 people as sample. The sample is taken using proportional random sampling technique and data collection uses questionnaire and is analyzed using SEM program of AMOS 22 technique analysis. Conclusion of research result is: there is a direct relationship between: (1) attitude to profession of teacher with learning motivation, (2) library service with learning motivation, (3) motivation with learning achievement. There is also indirect relationship between: (4) attitude to profession of teacher with learning achievement through motivation, and (5) library service with learning achievement through motivation.
\end{abstract}

Keywords: teacher profession, library service, learning motivation, learning achievement

\section{INTRODUCTION}

Student's learning achievement is influenced by student's motivation itself and something else outside the student; such as curriculum, lecturer, campus facilities along with its environment. According to Sardiman (2006), factors effect on to student's learning achievement are: (1) internal factor, such as: enthusiasm, talent, seriousness, (2) external factors, for instance: environment, parents, economics, politics, and (3) physical factor related to health, physical and mental perfection. Student's learning achievement which is obtained by student are a result of interaction within, for example student's attitude to teacher's profession and learning motivation, also from external factor of student itself, for example quality of lecturer and library service. The measurement of learning achievement can be seen by looking at the Grade Personal Accumulation (GPA), which is counted every semester based on Credit Semester (CS) from each subject programmed. Syah (2010) stated that learning success can be scored by: (1) cognitive achievement can be done by written and attitude test. (2) affective achievement, arrange instrumental test in affective dimension. (3) psychomotor achievement, evaluate learning achievement which is on psychomotor dimension and able to be done through direct observation to the event(s), attitude or other phenomena.

Attitude is a reaction of someone which tends to accept or refuse something. Profession is a type of work which needs skills and uses scientific technique to do. Skills and scientific techniques can be achieved by special education with responsible curriculum. According to Yamin (2007), teacher is a profession, because a teacher must have knowledge, skill, and ability in running his work. Thereby, attitude to teacher's profession is a response, feel happy or not, support or not, agree or disagree to teacher's profession. Indicator of attitude measurement to teacher's profession are: (1) attitude to teacher's profession is positive; (2) attitude to importance of teacher's profession; (3) attitude to expectancy; (4) background of teacher's profession; (5) teacher's profession base; (6) responsibility to teacher's profession; (7) teacher's profession service oriented; (8) teacher's profession required; and (9) teacher's profession needs discipline.

Library service is an activity oriented to consumer pursuant based on national library standard which is developed as the progress of information technology and communications. According to Hastuti (2012), type of library service, for example: circulation service, reference service, information service, translation service, copying service. According to Parasuraman, et.al (2005:133), measuring rod of library service are: (1) reliability, that is an ability to give service correctly, accurately, and trustworthily; (2) responsiveness, that is a willingness to assist and give service swiftly; (3) assurance, that is an ability to grow a trust; (4) empathy, for instance: good communications, attention of requirement, and trying to know a wish; (5) tangibles (physical evidence), that is an ability in showing existence and appearance, abilities, facilities, and environment are some real evidences.

Another factor which influences learning achievement is motivation. According to Sardiman (2006), motivation can optimize learning achievement; 
higher motivation strength had by a student, higher indeed his learning achievement. Learning motivation correlate to student's learning achievement, because learning motivation can lift up the student to learn and focus his activity on his learning purpose. The role of motivation is also important because it can grow the spirit and happiness of someone to study, so that learning achievement increased. The indicator of learning motivation: (1) desire to be successful; (2) spirit and motivation of learning; (3) aspiration and expectation; (4) appreciation; (5) interesting activity; (6) conduciveness of learning environment (Uno, 2008).

\section{METHODS}

This research is a survey research with correlation type and use sampling technique to take a sample of population which is assumed representative, while the fundamental data collector is a questioner. Data analysis in this research uses SEM which consists of seven steps, those are: (a) development of theory based model, (b) path construction diagram, (c) structural and measurement model, (d) estimation model, (e) identify structural model, (f) evaluation based on goodness of fit criteria, and (g) modification and interpretation model. Development of theoretical model pursuant to theory as a base in connecting one latent variable with another latent variable is including on its indicators. Causal relations between variables are not visualized in form of a picture of variables relation so it will be easier and clearer to be understood and also more interesting. If the model result is not good enough, it should modify the model, so that the obtained model will be better. In the endogen construction, endogen variable can predict one or more the other endogen variables, while in exogenous variable, among exogenous variables cannot predict each other but only do reciprocal relationship.

\section{RESULT AND DISCUSSION}

\section{A. Validity and Reliability Test}

Validity test is conducted to identify a capacity of statement list of measurement what ought to be measured. Criteria of validity examination done by comparing $r_{\text {count }}$ with $r_{\text {table }}$ at significant level $95 \%$ or $\leq$ $5 \%$ and statement item referred as valid at significant level $95 \%$ if the statement item has $r_{\text {count }}>r_{\text {table }}$ or $r_{\text {count }}$ $\geq 0,30$. Attitude student variable to teacher's profession is measured by 7 statement items, library service is measured by 9 statement items, learning motivation is measured by 13 statement items, and learning achievement is not questioned in the questioners because the data obtained from pertinent student or archives administration of each academic. Based on the data processing, it is obtained that all statement items have coefficient of $r_{\text {count }}>0.3$, so that can be told that all statement items are valid.

Reliability test is aimed to measure the consistency of research instrument and variable construction is reliable if it has a Cronbach's value > 0,60 . Based on calculation result, there is no construct reliability value on $<0,60$, means that all construct in this research is competent to be used in entire model and attribute at the variable is consistent and can be trusted (reliable) and also be used for the process of research.

Table 1

Variable Validity

\begin{tabular}{|c|c|c|c|c|c|}
\hline Var & Total & Var & Total & Var & Total \\
\hline $\mathrm{x} 1$ & $.485^{* *}$ & $\mathrm{x} 11$ & $.742^{* *}$ & $\mathrm{y} 5$ & $.660^{* *}$ \\
\hline $\mathrm{x} 2$ & $.477^{* *}$ & $\mathrm{x} 12$ & $.779^{* *}$ & $\mathrm{y} 6$ & $.666^{* *}$ \\
\hline $\mathrm{x} 3$ & $.437^{* *}$ & $\mathrm{x} 13$ & $.761^{* *}$ & $\mathrm{y} 7$ & $.723^{* *}$ \\
\hline $\mathrm{x} 4$ & $.521^{* *}$ & $\mathrm{x} 14$ & $.738^{* *}$ & $\mathrm{y} 8$ & $.695^{* *}$ \\
\hline $\mathrm{x} 5$ & $.403^{* *}$ & $\mathrm{x} 15$ & $.748^{* *}$ & $\mathrm{y} 9$ & $.676^{* *}$ \\
\hline $\mathrm{x} 6$ & $.422^{* *}$ & $\mathrm{x} 16$ & $.729^{* *}$ & $\mathrm{y} 10$ & $.700^{* *}$ \\
\hline $\mathrm{x} 7$ & $.448^{* *}$ & $\mathrm{y} 1$ & $.686^{* *}$ & $\mathrm{y} 11$ & $.702^{* *}$ \\
\hline $\mathrm{x} 8$ & $.686^{* *}$ & $\mathrm{y} 2$ & $.650^{* *}$ & $\mathrm{y} 12$ & $.939^{* *}$ \\
\hline $\mathrm{x} 9$ & $.770^{* *}$ & $\mathrm{y} 3$ & $.599^{* *}$ & $\mathrm{y} 13$ & $.878^{* *}$ \\
\hline $\mathrm{x} 10$ & $.736^{* *}$ & $\mathrm{y} 4$ & $.694^{* *}$ & $\mathrm{y} 14$ & $.864^{* *}$ \\
\hline
\end{tabular}

Table 2

Variable Reliability

\begin{tabular}{|c|c|}
\hline Cronbach's Alpha & N of Items \\
\hline 0.933 & 30 \\
\hline
\end{tabular}

\section{B. Analysis of Data Result of Research}

\section{Analysis Assumption of SEM}

Analysis of assumption of SEM preceded with test of normality data as a mean to know that obtained data is normal distribution data. Test of normality data uses the calculation of critical value of skewness and kurtosis. Skewness test used to see the inclination of data spreading, while kurtosis test used to see the sharpness of data spreading. According to Suharyadi (2003), data have a dissemination which is incline if critical value for skewness is among $\pm 3,00$, and have spreading of sharp-pointed data if critical value for 
kurtosis > 3.00. While Ferdinand (2002) stated that data disseminate normal if critical value for the skewness and kurtosis is not bigger than $\pm 2,58$. Based on result of data processing obtained that critical value of skewness and kurtosis altogether fulfill so that it can be said that the data disseminate normally.

\section{Analysis of Confirmatory Factor}

Analysis of confirmatory factor is used to test unidimensionality of dimensions explaining that the entire indicators used in research are shape of student's attitude variable to teacher's profession, library service, and learning motivation. This analysis of confirmatory factor is also meant to analyze the validity level of existing data in research, which means indicator used must have a meaning to form a formed variable. Significant indicator confirms the variable if it owns lambda coefficient $\geq 0,50$ and critical value (c.r) $\geq 0,20$ and also probability $<0,05$ (Ferdinand, 2002).

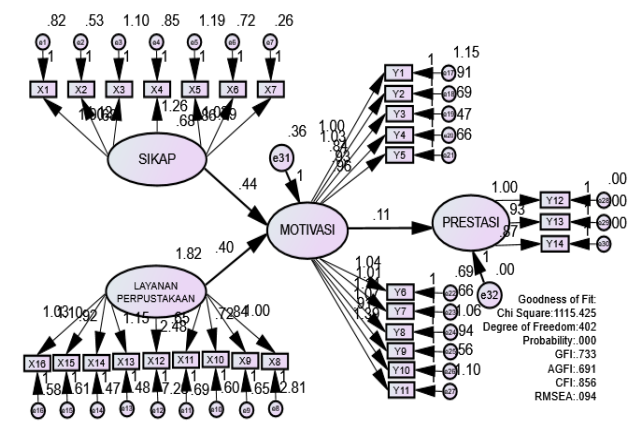

Picture 1

Confirmatory Factor Analysis Variable Research

Tables 3

Evaluation of Goodness of Fit

\begin{tabular}{cccc}
\hline Indek & $\begin{array}{c}\text { Value } \\
\text { criterion }\end{array}$ & Result & $\begin{array}{c}\text { Model } \\
\text { evaluation }\end{array}$ \\
\hline Chi Square & $\begin{array}{c}\text { expected } \\
\text { small }\end{array}$ & 1115.425 & unfavourable \\
Probability & $\geq 0.05$ & 0.000 & unfavourable \\
CMIN/DF & $\leq 2.00$ & 2.775 & marginal \\
GFI & $\geq 0.90$ & 0.793 & unfavourable \\
AGFI & $\geq 0.90$ & 0.691 & unfavourable \\
CFI & $\geq 0.95$ & 0.856 & marginal \\
RMSEA & $\leq 0.08$ & 0.094 & good \\
\hline
\end{tabular}

\section{Analysis of Goodness Fit of Test}

Goodness of fit test or eligibility test model used to measure accuracy of function of sample regression in determining actual value. Statistically, goodness of fit test can be done through a measurement of coefficient value determinacy, statistical value of $\mathrm{F}$, and statistical value of $\mathrm{t}$.

Based on data processing result, there are 4 criteria which are not fulfilled from 7 criteria used as guidance, 2 marginal criteria and only 1 good value. According to Solimun (2004:71), if there are still unfulfilled criteria from 7 required criteria, it can be told that the model is not good yet and can be conducted a modification at the model. The modification can be conducted by correlating some error which has big Modification Indices (M.I) > 10.000 


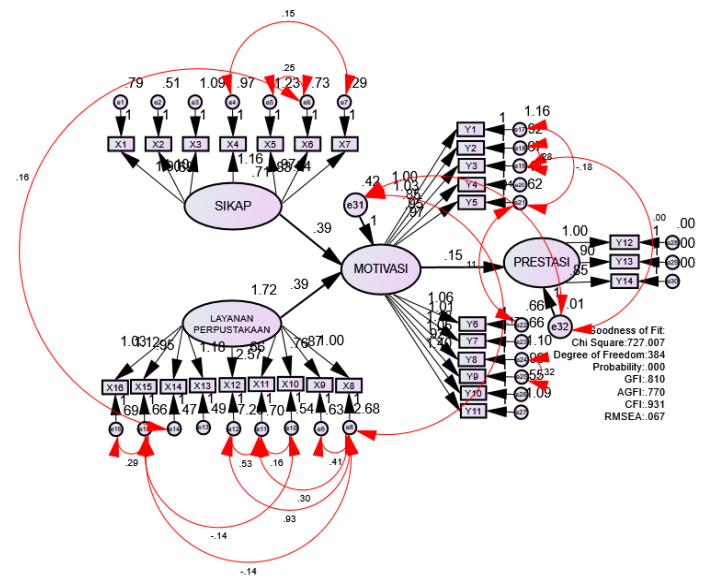

Picture 2

Modification Model

Based on data processing result, it can be seen that modification model showing repairing value or better value to all existing indicators. Value criteria are almost better in everything except on the probability which do not have any changes or remains. Besides, there is obtained 1 indicator fulfilling RMSEA, so that the modification model is more up to standard. Regression Weight between endogen and exogenous variable obtained 3 better relations of regression coefficient and only 1 worse in regression coefficient. As for value of squared multiple correlation got that both of them improved, in achievement and learning motivation.

Based on the description above, it can be said that modification model can make an equal model there are 2 indicators fulfilling (CMIN/DF and RMSEA) and the model is seen better so that there is no need to do a further modification (Solimun, 2004).

Table 4

Comparison of Based Model and Modification Model

\begin{tabular}{ccccc}
\hline Indek & $\begin{array}{c}\text { Value } \\
\text { criterion }\end{array}$ & $\begin{array}{c}\text { Based } \\
\text { model } \\
\text { result }\end{array}$ & $\begin{array}{c}\text { Modification } \\
\text { result }\end{array}$ & $\begin{array}{c}\text { Model } \\
\text { evaluation }\end{array}$ \\
\hline Chi & expected & 1115.43 & 727.01 & better \\
Square & small & 0.000 & 0.000 & constant \\
Probability & $\geq 0.05$ & 2.775 & 1.893 & good \\
CMIN/DF & $\leq 2.00$ & 0.793 & 0.81 & better \\
GFI & $\geq 0.90$ & 0.691 & 0.77 & better \\
AGFI & $\geq 0.90$ & 0.856 & 0.931 & marginal \\
CFI & $\geq 0.95$ & 0.094 & 0.067 & good \\
RMSEA & $\leq 0.08$ & & & \\
\hline
\end{tabular}

Table 5

Standardized Regression Weights

\begin{tabular}{|l|l|l|c|c|c|c|c|}
\hline & & & Estimate & S.E. & C.R. & P & Label \\
\hline MOT & $<--$ & SIK & 0.393 & 0.063 & 6.209 & $* * *$ & par_28 \\
\hline MOT & $<-$ & LAY & 0.386 & 0.054 & 7.141 & $* * *$ & par_29 \\
\hline PRE & $<-$ & MOT & 0.151 & 0.015 & 9.783 & $* * *$ & par_27 \\
\hline
\end{tabular}

Table 6

Regression Weight

\begin{tabular}{|l|l|l|c|c|c|c|c|}
\hline & & & Estimate & S.E. & C.R. & P & Label \\
\hline MOT & $<--$ & SIK & 0.393 & 0.063 & 6.209 & $* * *$ & par_28 \\
\hline MOT & $<--$ & LAY & 0.386 & 0.054 & 7.141 & $* * *$ & par_29 \\
\hline PRE & $<--$ & MOT & 0.151 & 0.015 & 9.783 & $* * *$ & par_27 \\
\hline
\end{tabular}




\section{Equation Structural Analysis Model}

Model Analysis uses coefficient of regression for the variable of attitude to teacher's profession, service library to motivation and learning achievement and result is in the form of value of Standardized Regression Weights and Regression Weights.

Direct relationship attitude variable to teacher's profession to motivation owning Standardized Regression Weights is 0,374, with CR (Critical Ratio) is identical with value 6,209 at probability $* * *$. CR value $=6,209>2,000$ and probability $=* * *<0,05$ indicating that statistically at level $\alpha=0,05$ the influence of attitude variable to teacher's profession to positive motivation isn't equal to 0,374 , means if attitude to teacher's profession increases 1 unit, so the motivation increases 0,374 unit. It is according to Walgito's opinion (in Muhson, 2006:16) stating that attitude contains feeling factor and motivation, means that attitude to an object will be always followed by feeling of which can be positive or negative to the object. Attitude also contains motivation, means that attitude have a stimulus for individual to behave particularly to the faced object.

Attitude contains feeling and motivation factor. it means that attitude to teacher's profession will be always followed by selected feeling which is able to generate a feeling to like or dislike to teacher's profession. The feeling also generates a motivation or stimulus to behave to teacher's profession. If attitude to teacher's profession generates feeling of like, there will be a motivation to get closer or have a spirit to be a teacher.

Direct relationship between library service variable to motivation owning standardized direct effect regression weights equals to 0,570 , with $\mathrm{CR}$ value equals to 7,141 at probability $* * *$. $\mathrm{CR}$ value $=$ $7,141>2,000$ and probability $=* * *<0,05$ shows that statistically at $\alpha$ level $=0,05$ influences Library service variable to positive motivation is 0,570 , means if library service increase 1 unit, motivation will increase for 0,570 unit. Herzberg (in Kluytmans, 2006:35) stated that there is an extrinsic motif which comes out from someone's outside and intrinsic motif from the individual's inside. Further, Herzberg theory expressed that one of extrinsic which is impeller energy from individual's outside is environmental atmosphere and condition of the library itself. Balmy condition and calm atmosphere in the library very influence consumer in using the library service.

Direct relationship of motivation variable to learning achievement owning equal to 1,302, with CR equal to 9,783 at probability $* * *$. $\mathrm{CR}$ value $=9.783>$ 2,000 and probability $=* * *<0,05$ showing that statistically at $\alpha$ level $=0,05$ the influence of motivation variable to positive learning achievement equals to 1,302 , means if motivation increases 1 unit, the learning achievement will increase 1,302 unit. According to Mc Celland (in Notoadmodjo, 2002), there are two motivation in human being, that is primary and secondary motivation. Primary motivation is not studied because it is naturally in each human being biologically, while secondary motivation is arising from the outside of someone as a consequence of social interaction or others. One of social motivations is a motivation for having achievement, that is motivation which is in each human being to reach good result or activity work maximally. Instinctively each and everyone have desire to do the activity differ from others and better than others. However, this matter often finds many constraints. Therefore, achievement motivation is a stimulus to be successful in any situation of competition based on their excellent comparing to others.

Indirect relationship of attitude variable to teacher's profession to learning achievement through motivation have standardized direct effect regression weights value of $=(0,374 * 1,302)=0,487$.

According to previous description, it is all known that direct influence of attitude variable to teacher's profession to positive motivation is significant and direct influence of motivation variable to learning achievement is also positive significant, so that it can be said that indirect influence of attitude variable to teacher's profession to learning achievement through motivation is significant, means if attitude to teacher's profession increases, the learning achievement will also improve. Learning motivation which had by student in every single learning activity influences to increase the learning achievement in each subject (Nashar, 2004:11). Highly motivated student in learning is able to get high learning result also, it also means the higher motivation and intensity of effort and struggle, higher also its learning achievement of him. According to Alderfer (in Nashar, 2004:42), learning motivation is a tendency of student in conducting learning activity which is supported to get learning achievement as good as possible. Motivation is viewed as a stimulus to bounce moving and instructing behavior of human being including learning behavior.

Indirect relationship of library service variable to learning achievement through motivation have standardized direct effect regression weights equal to: $(0,570 * 1,302)=0,752$.

Based on the preceded description known that direct influence of library service variable to positive motivation is significant and direct influence of motivation variable to learning achievement is also positive significant, so that it can be said that indirect influence of library service variable to learning achievement through motivation is significant, means if library service increase, learning achievement will increase also. Library has a responsibility and a role to provide and always improve the quality of service in the form of assorted information, especially related to academic activity to enrich knowledge of public (Rohman, et al, 2012:2). If library has good quality in service, it will make student interested to come to library, so the academic activity related to learning achievement will also run better.

\section{Analysis of Measurement Model}

Analysis of measurement model with determinacy used to know the level of variable contribution of exogenous to endogen seen value of square multiple correlation. According to Ferdinand 
(2002:114), value of square multiple correlation identically with $\mathrm{R}^{2}$ at program of SPSS, so that according to data processing result of this level of determinacy for the variable of motivation $=0,464 \mathrm{x}$ $100 \%=46,45 \%$, means the changes of motivation influenced by attitude to teacher's profession and library service equal to $52,5 \%$. As for value of determinacy for the variable of learning achievement $=$ $0,523 \times 100 \%=52,3 \%$, means the changes of learning achievement to be influenced by attitude to teacher's profession, library service, and motivation equal to $52,3 \%$.

Table 7

Square Multiple Correlation

\begin{tabular}{|l|r|}
\hline & Estimate \\
\hline MOTIVASI & 0.464 \\
\hline PRESTASI & 0.523 \\
\hline
\end{tabular}

Based on the analysis as a whole can be concluded that any attitude variable indicators to teacher's profession, library service to motivation and learning achievement is valid. At analysis of structural equation model, there are two variable owning positive direct influence is significant to motivation, one variable owning positive direct influence is significant also to learning achievement, and there are two variable owning positive indirect influence is significant to learning achievement.

\section{A. Conclusion}

According to data analysis result and study of variables data: attitude to teacher's profession, library service, motivation, and learning achievement, can be taken conclusion:

1. Direct relationship of aAttitude to teacher's profession to learning motivation is significant. If student has good attitude to teacher's profession, the learning motivation of him will be high.

2. Direct relationship of library service to learning motivation is significant. If library service is good, the learning motivation of student will be high.

3. Direct relationship of motivation to learning achievement is significant. If student motivation is high, the learning achievement will be high also

4. Indirect relationship of attitude to teacher's profession to learning achievement through motivation is significant. If attitude to teacher's profession improve, the learning achievement is also motivated

5. Indirect relationship of library sService to learning achievement through motivation is significant. If library service is good, the learning achievement will be in high motivation.

\section{B. Suggestion}

Based on the result of data processing above, can be suggested as follows

1. Student. Student especially for student of STKIP have to realize that after graduating from bench of college, they will become teachers. Therefore, student should have positive attitude to teacher's profession because it will influence their learning motivation and it is of course will have an effect on the improvement of their learning achievement.
2. Development of science, especially management of education. this research Result indicates that attitude to teacher's profession, and library service have a direct and indirect effect on learning motivation to student's learning achievement. Therefore, in education management of science especially educative participant management can be added by attitude to teacher's profession and special service management concerning library can be added by library service. If this problem can be accomplished, it will make educative participant or active student develop himself, the overcoming of problem of education quality, and the increasing of positive education image.

\section{REFERENCES}

[1] Arbuckle, J. L. 1997. Amos Users' Guide. Version 3.6. Chicago: Smallwaters Corporation.

[2] Ferdinand, F. A. 2002. Structural Equation Modelling dalam Penelitian Manajemen. Semarang: BP Undip.

[3] Ghozali, I. 2004. Model Persamaan Struktural Konsep dan Aplikasi dengan Program Amos Ver, 5.0. Semarang: Badan Penerbit Universitas Diponegoro.

[4] Hastuti. 2012. Psikologi Perkembangan Anak. Yogjakarta: Tugu Publisher.

[5] Kluytmans, F. 2006. Perilaku Sikap: Pengantar Singkat Tentang Psikologi. Bandung: Refika Aditama.

[6] Muhson, A. 2004. Meningkatkan Profesionalisme Guru. Jurnal Ekonomi dan Pendidikan, 2(1).

[7] Nashar. 2004. Peranan Motivasi dan Kemampuan Awal. Jakarta: Delia Press.

[8] Notoatmodjo, S. 2003. Pengembangan Sumber Daya Manusia. Jakarta: Rineka Cipta.

[9] Parasuraman, A., Zeithamyl, V. A., and Malholtra, A. 2005. SERVQUAL: A MultipleItem Scale for Assessing Electronic Service Quality. Journal of Service Research, 7(X): 1-21.

[10] Ridwan. 2009. Pengantar Statistika Sosial. Bandung: Alfabeta.

[11] Rohman, M., and Sofan, A. 2012. Manajemen Pendidikan. Jakarta: Prestasi Pustakaraya.

[12] Sardiman, A. M. 2006. Interaksi dan Motivasi Belajar Mengajar. Jakarta: Raja Garfindo Persada. 
[13] Sardiman, A. M. 2007. Interaksi Belajar Mengajar. Jakarta: RajaGrafindo.

[14] Solimun, M. S. 2002. Structural Equation Modelling, Lisrel dan Amos. Paper Presented in Diklat Angkatan II, Brawijaya University, Malang, 11-13 March 2002.

[15] Sugiyono. 2007. Metode Penelitian Pendidikan. Bandung: Alfabeta.

[16] Suryabrata, S. 2008. Metodologi Penelitian. Jakarta: PT Raja Grafindo Persada.

[17] Syah, M. 2010. Psikologi Penddikan dengan Pendekatan Baru. Bandung: Rosda.

[18] Uno, H. B. 2008. Profesi Kependidikan, Problema, Solusi, dan Reformasi Pendidikan di Indonesia. Jakarta: Bumi Aksara.

[19] Yamin, M. 2007. Profesionalisasi Guru \& Implementasi KTSP. Jakarta: Gaung Persada Press.

[20] Zulganef. 2006. Pemodelan Persamaan Struktural \& Aplikasinya Menggunakan Amos 5. Bandung: Pustaka. 